\title{
ZASKARŻANIE WYROKÓW ZAPADŁYCH W TRYBACH KONSENSUALNYCH - STANDARD EUROPEJSKI I PRAWO POLSKIE
}

Europejska Konwencja Praw Człowieka w pierwotnym brzmieniu nie przewidywała standardu określającego warunki wnoszenia odwołań w sprawach karnych. Został on wprowadzony do palety praw człowieka gwarantowanych przez Radę Europy na mocy Protokołu nr $7^{1}$. Jak wskazuje się w doktrynie europejskiej, państwa członkowskie RE korzystają ze znacznej swobody we wprowadzaniu postanowień tego Protokołu do ustawodawstw narodowych ${ }^{2}$.

Art. 2 tego Protokołu stanowi:

1. Każdy, kto został uznany przez sąd za winnego popełnienia przestępstwa, ma prawo do rozpatrzenia przez sąd wyższej instancji jego sprawy tak w przedmiocie orzeczenia o winie, jak i co do kary. Korzystanie z tego prawa, a także jego podstawy, uregulowane są przez prawo.

2. Wyjątki od tego prawa mogą być stosowane w przypadku drobnych przestępstw, określonych w ustawie, lub w przypadkach, gdy dana osoba była osądzona w pierwszej instancji przez Sąd Najwyższy lub została uznana winną lub skazana w wyniku zaskarżenia wyroku uniewinniającego sądu pierwszej instancji.

Jak wskazuje się w polskiej literaturze przedmiotu, wprawdzie uprawnienie określone w art. 2 Protokołu nr 7 nie należy do gwarancji składających się na prawo do rzetelnego procesu sensu largo, jednakże jest ono istotne, jeśli będzie postrzegane przez pryzmat art. $6 \mathrm{EKPCz}$, co wynika z następujących względów3

\footnotetext{
$1 \quad$ Protokół ten został wprowadzony jako poprawka przez Protokół nr 11 (ETS No. 155), który wszedł w życie 1 listopada 1998 r. Warto dodać, że Protokół ten został ratyfikowany przez wszystkie państwa członkowskie Rady Europu z wyjątkiem Belgii, Niemiec, Holandii, Turcji i Wielkiej Brytanii.

2 E. Cape, (w:) E. Cape, Z. Namoradze, R. Smith, T. Spronken (red.), Effective Criminal Defence in Europe, Antwerp-Oxford-Portland 2010, s. 52.

3 C. Nowak, Prawo do rzetelnego procesu sądowego w świetle EKPCz i orzecznictwa ETPC, (w:) P. Wiliński (red.) Rzetelny proces karny, Warszawa 2009, s. 145-146.
} 
1. Dotyczy ono spraw karnych w rozumieniu art. 6 EKPC, a zatem spraw, do których mają zastosowanie gwarancje rzetelnego procesu ${ }^{4}$.

2. Skargi dotyczące naruszenia prawa do odwołania w sprawach karnych najczęściej wnoszone są przy okazji skarg o naruszenie prawa do rzetelnego procesu, o których mowa w art. 6 EKPC. Dlatego też należy uznać, że uprawnienie określone w art. 2 ust 1 Protokołu nr 7 uzupełnia katalog gwarancji składających się na prawo do rzetelnego procesu sądowego sensu largo. Orzecznictwo ETPCz wyraźnie wskazuje, że rozpoznając odwołanie sąd wyższej instancji musi spełniać wszystkie warunki wynikające $\mathrm{z}$ art. 6, mające zastosowanie do postępowania odwoławczego. Również postępowanie kasacyjne należy uważać za zbadanie sprawy w rozumieniu tego artykułu.

Zgodnie z art. 2 ust. 1 Protokołu nr 7, każdy, kto został uznany przez sąd za winnego popełnienia przestępstwa, ma prawo do rozpatrzenia przez sąd wyższej instancji jego sprawy, zarówno w przedmiocie orzeczenia o winie, jak i co do kary. Korzystanie z tego prawa, a także jego podstawy reguluje ustawa. Prawo to odnosi się jedynie do spraw, które uznane są za sprawy karne w świetle EKPC ${ }^{6}$ oraz orzeczeń wydanych przez organy, które uznane są za sądy na podstawie art. $6 \mathrm{EKPCz}$.

Uprawnienie to dotyczy orzeczeń zarówno o winie, jak i karze. Jeśli więc oskarżony przyznaje się do winy, możliwość skorzystania przez niego z prawa gwarantowanego na podstawie art. 2 ust. 1 Protokołu nr 7 może zostać ograniczona w prawie krajowym do odwołania od orzeczenia o karze ${ }^{7}$. W doktrynie odnosząc to ograniczenie do wyroków zapadających w trybie konsensualnym, gdzie sąd akceptuje porozumienie zawarte pomiędzy oskarżeniem i obroną, uznaje się za usprawiedliwione zaskarżenie apelacją tych elementów, które objęło porozumienie. Jednocześnie jednak krytykuje się ograniczenie zakresu zaskarżenia wyroków jedynie co do wymiaru kary podnosząc, że przyznanie się do winy nie może być interpretowane jako w ogóle rezygnacja z wnoszenia środka odwoławczego od wyrokus.

Przepisy prawa krajowego określają tak warunki skorzystania z przedmiotowego uprawnienia, jak i podstawy jego stosowania. W związku z powyższym fakt, że w niektórych państwach postępowanie odwoławcze ogranicza się do analizy kwestii prawnych, czy też to, że w niektórych systemach oskarżony musi zwrócić

\footnotetext{
4 Zob. także R. Broniecka, Uzasadnianie wyroku w polskim postępowaniu karnym, Warszawa 2011, s. 142 i podane tam orzecznictwo ETPCz.

$5 \quad$ M. Nowicki, Wokół Konwencji Europejskiej. Komentarz do EKPCz (6 wyd.), Warszawa 2013, s. 935 i podane tam orzecznictwo ETPCz. Zob także P. Hofmański, (w:) L. Garlicki (red.), Konwencja o ochronie praw człowieka i podstawowych wolności, t. 2. Komentarz do art. 19-59 oraz do protokołów dodatkowych Warszawa 2011, s. 630-631.

$6 \quad$ Decyzja z dnia 2 września 1993 r., 17571/90, Borelli v. Szwajcaria, D.R. 75.

7 Protocol No. 7 to the Convention for the Protection of Human Rights and Fundamental Freedoms. Explanatory report. (Komentarz do Protokołu nr 7), dostępny na stronie http://conventions.coe.int/Treaty/en/Reports/Html/117. htm, pkt 17.

8 P. Hofmański, Konwencja..., op. cit., s. 635-637.
} 
się o wstępne pozwolenia na wniesienia odwołania, należy uznać za nie kolidujące $\mathrm{z}$ analizowanym przepisem ${ }^{9}$. Z brzmienia art. 2 ust. 1 Protokołu wynika, że również ustawodawstwom krajowym pozostawiono kwestię zakresu zarzutów odwoławczych (a więc i ich ewentualnych ograniczeń, np. wyłączenie spod kontroli ustaleń faktycznych), jednakże pod warunkiem, że nie dochodzi przy okazji do zaprzeczenia istoty danego środka odwoławczego ${ }^{10}$.

ETPCz w swoim orzecznictwie wskazuje na konieczność zachowania równowagi pomiędzy z jednej strony zapewnieniem wykonania orzeczeń sądowych, z drugiej zaś zagwarantowaniem prawa dostępu do sądu i praw obrony. W tym kontekście w szeregu orzeczeń przeciwko Francji Trybunał w Strasburgu stwierdził, że sprzeczne z podstawowymi gwarancjami rzetelnego procesu zawartymi w art. 6 EKPCz jest uznanie za niedopuszczalne odwołania opartego na zarzucie naruszenia prawa wyłącznie na podstawie sprzeciwu odwołującego się wobec umieszczenia go w areszcie. Takie bowiem decyzje sądu zmuszają odwołującego się do poddania się wcześniej pozbawieniu wolności wynikającego orzeczenia sądu I instancji, które nie jest ostateczne, dopóki nie podejmie decyzji sąd odwoławczy bądź nie upłynie termin na złożenie środka odwoławczego ${ }^{11}$.

Prawo do odwołania nie jest prawem bezwzględnie obowiązującym, dopuszczalne są od niego wyjątki ${ }^{12}$. W świetle art. 2 ust. 2 Protokołu nr 7, wyjątki od tego prawa mogą być stosowane w przypadku drobnych przestępstw, określonych w ustawie, lub w przypadkach, gdy dana osoba była sądzona w I instancji przez Sąd Najwyższy (ze względu na pełnienie przez nią wysokiego urzędu państwowego, lub ze względu na charakter zarzucanego czynu ${ }^{13}$ ), bądź też uznana została za winną i skazana w wyniku zaskarżenia wyroku uniewinniającego sądu I instancji. Przy kwalifikowaniu czynu za drobne przestępstwo bierze się pod uwagę surowość grożącej za jego popełnienie sankcji, a w szczególności możliwość orzeczenia zań kary pozbawienia wolności ${ }^{14}$. Zgodnie ze stanowiskiem ETPC czyn zagrożony karą pozbawienia wolności w wysokości maksymalnie 15 dni nie stanowi drobnego przestępstwa i w związku z tym osoby skazane za popełnienie tego rodzaju czynów, chociażby na karę niższą, powinny móc skorzystać z gwarancji określonych w art. 2 Protokołu nr $7^{15}$.

Orzecznictwo ETPCz akcentuje, że ograniczenia prawa do odwołania określone w przepisach prawa krajowego muszą, przez analogię z prawem dostępu do sądu, wyprowadzonym $z$ treści art. 6 ust. 1 EKPC, wynikać z uzasadnionego celu i nie pro-

\footnotetext{
9 Zob powołany przez C. Nowak (op. cit., s. 146) wyrok ETPCz z dnia 7 grudnia 2006 r., 37301/03, Hauser-Sporn v. Austria, §52.

10 P. Hofmański, Konwencja..., op. cit., s. 637-638 i podane tam orzecznictwo ETPCz.

11 E, Cape i inni, op. cit., 52-53 i podane tam orzecznictwo.

12 Zob. P. Hofmański, Konwencja..., op. cit., s. 638-640 i podane tam orzecznictwo ETPCz.

13 Hauser-Sporn v. Austria, pkt 20.

14 Ibidem, pkt 21; zob. także wyrok ETPCz z dnia 30 listopada 2006 r., 75101/01, Grecu v. Rumunia, § 82.

15 Wyrok ETPC z dnia 15 listopada 2007 r., 26986/03, Galstyan v. Armenia, § 124; tak samo w wyroku ETPC z dnia 17 lipca 2008 r., 33268/03, Ashughyan v. Armenia, § 108-110.
} 
wadzić do naruszenia istoty uprawnienia do wniesienia odwołania ${ }^{16}$. Ponadto, skorzystanie z tego prawa nie może być uzależnione od uznania władz krajowych i musi być bezpośrednio dostępne osobom zainteresowanym ${ }^{17}$.

Warto również zauważyć orzecznictwo ETPCz wskazujące, że możliwość skutecznego zaskarżenia orzeczenia sądowego stanowi jedną z gwarancji prawa do obrony (jako aspektu rzetelnego procesu), a jednym z jego wymogów jest prawidłowe uzasadnienie takiego orzeczenia ${ }^{18}$. Na znaczenie prawidłowego uzasadniania orzeczeń dla zasady rzetelnego procesu wskazał ETPC chociażby w orzeczeniu ETPCz z dnia 19 kwietnia 1994 r. Van de Hurk v. Holandia (§ 61), ETPC 16034/90. Zdaniem ETPCz oskarżony ma prawo poznania okoliczności, na jakich sąd opiera swoją decyzję, jak również same rozważania sądu, które doprowadziły go do określonych wniosków. Sądy krajowe muszą wystarczająco jasno wskazać, na czym opierały się przy podejmowaniu decyzji w sprawie, co umożliwi oskarżonemu świadome skorzystanie z prawa do wniesienia odwołania. Jednakże zgodnie z orzeczeniem ETPCz z dnia 16 grudnia 1992 r. w sprawie Hadjianastasiou v. Grecja, ETPCz 12945/87 (§ 33) obowiązek właściwego uzasadniania wyroków nie pociąga za sobą konieczności szczegółowego ustosunkowania się do każdego z argumentów stron. W orzecznictwie ETPCz wskazuje się także na istotny problem występujący na tle praktyki występującej w niektórych państwach, a przewidującej motywowanie wyroku tylko w razie wniesienia apelacji. Zdaniem Trybunału w Strasburgu w dużej mierze właśnie od sposobu uzasadnienia wyroku zależeć będzie treść wnoszonej przez oskarżonego apelacji, jak i w ogóle decyzja o jej wniesieniu ${ }^{19}$.

Nie ulega wątpliwości, że orzecznictwo ETPCz wpływa zarówno na ustawodawstwo, jak i przede wszystkim na orzecznictwo (także jako prejudykat) sądów krajów członkowskich Unii Europejskiej, w tym Polski ${ }^{20}$. Odnośnie do wzorców konstytucyjnych prawa do odwołania to art. 176 ust.1 Konstytucji RP ustanawia minimalny standard (co najmniej) dwuinstancyjności postępowania sądowego. Jak przyjmuje się w literaturze i orzecznictwie przez instancyjność należy rozumieć możliwość uruchomienia kontroli poprawności orzeczenia wydanego przez sąd orzekający co do meritum w sprawie. Jest to więc układ otwierający kontrolę orzeczenia sądu pierwszej instancji przez sąd wyższej instancji na skutek wniesienia środka

16 Wyrok ETPCz z dnia 13 lutego 2001 r., 29731/96, Krombach v. Francja, § 96.

17 Wyrok ETPCz z dnia 6 września 2005 r., 61406/00, Gurepka v. Ukraina, § 59.

18 Zob. C. Kulesza, R. Starzyńska, Obowiązek uzasadniania orzeczeń sądowych a prawo do obrony, „Prokuratura i Prawo” 2010, nr 5; R. Broniecka, Uzasadnianie wyroku..., op. cit., s. 133-140 i podane tam orzecznictwo ETPCz. Zob. także E. Cape i inni, op. cit., s. 50-51 i powołane tam orzecznictwo ETPCz. Warto zauważyć, że w polskiej literaturze poświęconej prawu do obrony, którego gwarancją jest także możliwość zaskarżania decyzji sądu, niekiedy nie dostrzega się tego aspektu zagadnienia, por. P. Wiliński, Zasada prawa do obrony w polskim procesie karnym, Kraków 2006, s. 412-413.

19 C. Nowak, Prawo do rzetelnego procesu sądowego..., op. cit., s. 144-145 i podane tam orzecznictwo ETPC oraz literatura.

20 Zob. M. Wąsek-Wiaderek, Samodzielność jurysdykcyjna sądu karnego wobec kompetencji Trybunału Konstytucyjnego i Trybunałów Europejskich, Lublin 2012, s. 364-393; B. Gronowska, Europejski Trybunał Praw Człowieka. W poszukiwaniu efektywnej ochrony praw jednostki, Toruń 2011, s.163-166 oraz 261-308. 
odwoławczego $^{21}$. W systemie instancyjnym sąd ten jest oznaczany jako sąd pierwszej instancji, dla odróżniania od sądu, który powołany został do dokonania kontroli, określanego mianem sądu drugiej instancji. Istniejący model oznacza uruchomienie co najmniej dwóch etapów postępowania sądowego - rozpoznania sprawy i kontroli poprawności rozpoznania. Przepis art. 176 ust. 1 Konstytucji stanowi przepis szczególny w stosunku do art. 78 Konstytucji, gdyż pierwsza regulacja wskazuje prawo do odwołania od każdego orzeczenia bez względu na podmiot rozstrzygający, zaś drugi, ustalając wyższy standard, odnosi się jedynie do postępowania sądowego ${ }^{22}$. Tym samym gwarancje wynikające z art. 176 ust. 1 Konstytucji nie odnoszą się do postępowań prowadzonych od początku przed innymi niż sąd organami.

Powyższą tezę podziela także postanowienie SN z dnia 02.02.2012 r. (III SO 21/11, LEX nr 1215452):

„1. Zawarte w art. 176 ust. 1 Konstytucji Rzeczypospolitej Polskiej pojęcie ,instancji” należy odnosić do przedmiotu całego postępowania, a nie do przedmiotu konkretnego rozstrzygnięcia, także incydentalnego.

2. Wynikająca z art. 176 ust. 1 Konstytucji Rzeczypospolitej Polskiej zasada dwuinstancyjności postępowania sądowego obowiązuje tylko w sprawach rozpoznawanych od początku do końca przez sądy. Określone w art. 78 Konstytucji Rzeczypospolitej Polskiej prawo do zaskarżania obejmuje natomiast rozstrzygnięcia wydawane w pierwszej instancji we wszystkich postępowaniach prowadzonych przez organy władzy publicznej, ale nawet w tym zakresie ustawa może przewidywać wyjątki w postaci niezaskarżalności rozstrzygnięć organów pierwszej instancji” (zob. także postanowienie SN z dnia 9 stycznia 2012 r., III SO 15/11, LEX nr 1163959).

W wyroku SK 46/08 TK podkreślił, że art. 176 ust. 1 uzupełnia treść art. 78 Konstytucji i konkretyzuje treść prawa jednostki do dwuinstancyjnego postępowania sądowego ${ }^{23}$.

Art. 78 stanowi, że każda ze stron ma prawo do zaskarżenia orzeczeń i decyzji wydanych w pierwszej instancji. Wyjątki od tej zasady oraz tryb zaskarżania określa ustawa. W doktrynie i orzecznictwie podkreśla się także, że art. 176 ust. 1 Konstytucji stanowi w pewnym sensie także rozwinięcie konstytucyjnego prawa do sądu, o którym mowa w art. 45 ust. 1 Konstytucji ${ }^{24}$. Zgodnie z tym artykułem:

\footnotetext{
21 P. Wiliński, Proces karny w świetle konstytucji, Warszawa 2011, s. 154 i podane tam orzecznictwo TK, tenże Rzetelny proces karny w świetle Konstytucji i orzecznictwa Trybunału Konstytucyjnego (w:) P. Wiliński (red.), Rzetelny proces karny Warszawa 2009, s. 339-344 oraz R. Broniecka, Uzasadnienie wyroku..., op. cit., s. 102-104. Zob. szerzej nt. prawa odwołania się do sądu z art. 78 Konstytucji, (w:) P. Wiliński, Proces..., op. cit., s. 149-153 i podane tam orzecznictwo TK.

23 Wyrok TK z dnia 13 lipca 2009 r.SK 46/08, OTK-A 2009, nr 7, poz. 109

24 Odnośnie prawa do sądu określonego w art. 45 Konstytucji zob. szerzej P. Wiliński, Proces..., op. cit., s. 109-146 i podane tam orzecznictwo TK.
} 
1. Każdy ma prawo do sprawiedliwego i jawnego rozpatrzenia sprawy bez nieuzasadnionej zwłoki przez właściwy, niezależny, bezstronny i niezawisły sąd.

2. Wyłączenie jawności rozprawy może nastąpić ze względu na moralność, bezpieczeństwo państwa i porządek publiczny oraz ze względu na ochronę życia prywatnego stron lub inny ważny interes prywatny. Wyrok ogłaszany jest publicznie.

Na wzajemny związek art. 45 ust. 1 Konstytucji i zasady instancyjności wskazał m.in. TK w wyroku SK 7/06, podkreślając, że sądowe procedury odwoławcze nie są oparte na systemie apelacyjnym, który polega na ponownym rozpatrzeniu sprawy w całości przez sąd drugiej instancji. Ograniczenia wynikają chociażby ze związania sądu drugiej instancji granicami środka odwoławczego ${ }^{25}$. Jednakże w tym kontekście warto wskazać na orzecznictwo SN podkreślające realność prawa do odwołania. Jak wskazał SN w wyroku z dnia 20.10.2010 r. (III CSK 323/09, LEX nr 725054): „Prawo do kontroli sądowej - podobnie jak prawo do sądu - ma na gruncie Konstytucji charakter autonomiczny. Nie chodzi zatem o formalne istnienie w danej sprawie co najmniej dwu instancji sądowych oraz ustanowienie powszechnego dostępnego środka zaskarżenia, ale o realne zagwarantowanie „każdemu” możliwości skorzystania z tego środka, przeniesienia sprawy do wyższej instancji i przeprowadzenia merytorycznej kontroli orzeczenia".

Dlatego też za uprawniony należy uznać pogląd, że Konstytucja ustanawia zasadę co najmniej dwuinstancyjnego postępowania sądowego, zaś regulacje obecnie obowiązujące polskiego k.p.k. hołdują zasadzie dwuinstancyjności, realizując zatem w tym zakresie standard minimalny. Konsekwencją istnienia tego przepisu na gruncie postępowania karnego jest obowiązek wprowadzenia przez ustawodawcę co najmniej środka odwoławczego, inicjującego postępowanie przed sądem odwoławczym w przedmiocie zapadłego w sądzie karnym pierwszej instancji rozstrzygnięcia w zakresie przedmiotu tego postępowania odwoławczy istnieć musi zatem od każdego wyroku wydanego przez sąd w pierwszej instancji. Konstytucja pozostawia jednak otwartą kwestię modelu środków odwoławczych i liczbę instancji odwoławczych w postępowaniu sądowym ${ }^{26}$.

W stanie prawnym obowiązującym do 1 lipca 2015 r. za podstawowe ograniczenie prawa do zaskarżenia wyroków zapadłych w trybie konsensualnym stanowi regulacja art. $434 \S 3$ stanowiącego, że sąd odwoławczy może orzec na niekorzyść oskarżonego także w wypadku skazania z zastosowaniem art. 343 lub art. 387 k.p.k. albo art. 156 k.k.s., jeżeli środek odwoławczy wniesiono na korzyść oskarżonego, 
zaskarżając rozstrzygnięcie co do winy lub co do kary lub środka karnego, objęte uprzednim porozumieniem.

Z kolei art. 434 § 5 przewiduje (w brzmieniu przed nowelizacją z 27.09.2013 r.), że przepisów $\S 3$ i $4^{27}$ nie stosuje się w przypadku stwierdzenia przez sąd odwoławczy przyczyn uzasadniających uchylenie orzeczenia, określonych w art. $439 \S 1$. Jak przyjął SN w postanowieniu z 30.10.2012 r. (II KK 22/12, LEX nr 1226684): „Umniejszenie gwarancji procesowych, o których mowa w art. $434 \S 3$ k.p.k. w odniesieniu do zaskarżania orzeczeń wydanych w jednym z tzw. trybów „skróconych”, w jednakowym stopniu dotyczy kwestionowania wyroku wydanego w wyniku porozumienia zawartego w trybie art. 343 k.p.k., jak i w trybie art. 387 k.p.k."

Warto więc dodać, że Trybunał Konstytucyjny w wyroku z dnia 28 kwietnia 2009 r. (P /22/07, (OTK-A 2009, nr 4, poz. 55) uznał, że zakaz reformationis in peius jest wprawdzie zakorzeniony w konstytucyjnym prawie do obrony, jednak nie należy do istoty tego prawa, a więc nie stanowi takiego elementu konstytucyjnego prawa do obrony, bez którego nie może ono istnieć. Trybunał podkreślił, że zakaz orzekania na niekorzyść oskarżonego bez wątpienia jest powiązany z prawem oskarżonego do zaskarżania orzeczeń zapadłych w jego sprawie. Dzięki obowiązywaniu tego zakazu zarówno przed sądem odwoławczym, jak i w postępowaniu ponownym (art. $434 \S 1$ i art. 443 k.p.k.) oskarżony w zasadzie nie ponosi ryzyka związanego z zaskarżeniem orzeczenia zapadłego w jego sprawie, ponieważ sąd nie może orzec wbrew kierunkowi zaskarżenia ${ }^{28}$.

Jednocześnie w kontekście trybów konsensualnych Trybunał stwierdził, że zakaz ten może podlegać ograniczeniom, z tym że dopuszczalność takich ograniczeń podlega ocenie z perspektywy konstytucyjnej zasady proporcjonalności art. 31 ust. 3 Konstytucji RP).

Ograniczenie stosowania zakazu reformationis in peius w przypadku wyroków, będących wynikiem porozumienia karnoprocesowego, takich jak dobrowolne poddanie się karze (art. 387 k.p.k.), uzasadnione jest zdaniem Trybunału samą istotą konsensualnych instytucji procesowych, których celem jest właśnie przyspieszenie i usprawnienie postępowania karnego, a tym samym zminimalizowanie konieczności orzekania przez sąd odwoławczy ${ }^{29}$.

W opinii Trybunału o ile wprowadzenie ograniczenia zakazu reformationis in peius wiąże się z zachowaniem oskarżonego, zmierzającym do zniweczenia celów zakładanych przez ustawodawcę, a więc ze złamaniem porozumienia karnoprocesowego, to w tym zakresie należy uznać, że powyższe ograniczenie zachowuje wła-

27 Art. 434 § 4 nie odnosi się do trybów konsensualnych, lecz do tzw. małych świadków koronnych i stanowi, że określonego w § 1 zakazu orzekania na niekorzyść oskarżonego nie stosuje się, jeżeli osoba, względem której zastosowano przepis art. 60 § 3 lub 4 Kodeksu karnego, lub art. 36 § 3 Kodeksu karnego skarbowego, odwołała swoje wyjaśnienia lub zeznania.

Uzasadnienie wyroku..., op. cit., s. 11-12. Zob. także J. Grajewski, S. Steinborn, (w:) L.K. Paprzycki (red.), Kodeks postępowania karnego. Komentarz (3 wydanie), t. II, Warszawa 2013, s. 66-67. 
ściwą miarę, proporcję między efektem ograniczenia a pewną dolegliwością dla jednostki. Służy bowiem przeciwdziałaniu sytuacji, w której oskarżony najpierw inicjuje dobrowolne poddanie się karze, a następnie dąży do podważenia wyroku, licząc na dalsze polepszenie swej sytuacji procesowej i korzystając z zakazu reformationis in peius. Natomiast w ocenie Trybunału trudno uznać zachowanie proporcjonalności sensu stricto $\mathrm{w}$ stosunku do wprowadzonego ograniczenia zakazu reformationis in peius w sytuacji, w której przyczyna uchylenia wyroku nie leży po stronie oskarżonego, lecz po stronie sądu. W takich przypadkach wyłączenie tego zakazu, a tym samym ograniczenie prawa do obrony, nie znajduje uzasadnienia $\mathrm{w}$ wartościach wskazanych w art. 31 ust. 3 Konstytucji RP i nie spełnia też warunków zasady proporcjonalności.

Dlatego też Trybunał ostatecznie uznał, że skutkiem jego wyroku jest dalsze obowiązywanie zakazu reformationis in peius, jeśli przyczyna uchylenia wyroku nie leży po stronie oskarżonego, lecz po stronie sądu. Tak więc będzie tu chodziło przede wszystkim o takie konfiguracje procesowe, w których oskarżony podnosi zasadne zarzuty obrazy przepisów prawa materialnego art. 438 pkt. 1 i przepisów prawa proceduralnego w zakresie niedotyczącym art. 387 (art. 438 pkt. 2) czy też wystąpią uchybienia stanowiące tzw. bezwzględne przyczyny odwoławcze (art. 439 k.p.k.) ${ }^{30}$.

Jak wskazuje się w komentarzach do art. 434 k.p.k. ustawodawca, przyjmując ustawę nowelizującą z 9 kwietnia 2010 r., która weszła w życie 1 lipca 2010 r., podjął próbę dostosowania brzmienia art. 434 i 443 do standardu wyznaczonego przez Trybunał Konstytucyjny w wyroku z 28 kwietnia 2009 r., jednakże była to próba wysoce nieudana, ${ }^{31}$ co skłoniło twórców nowelizacji k.p.k. dokonanej ustawą z dnia 27 września 2013 r. do nowego określenia regulacji art. 434 (o czym dalej).

Na tle obowiązującego stanu prawnego wypada jednak wskazać na postanowienie SN z dnia 2 lutego 2012 r. (II KK 5/12, LEX nr 1108450) stanowiącego, że:

1. Zarówno przepis art. $434 \S 3$ k.p.k., jak też art. 443 k.p.k. ma charakter zupełnie wyjątkowy i nie jest dopuszczalna ich rozszerzająca wykładnia.

2. Przepis art. 443 k.p.k. nie ma zastosowania w przypadku, gdy sąd odwoławczy ponownie rozpoznaje sprawę, na skutek uwzględnienia przez Sąd Najwyższy kasacji wniesionej na korzyść skazanego w warunkach określonych w art. 343 lub art. 387 albo art. 156 k.k.s. i uchylenia wyroku sądu drugiej instancji.

Za korzystny z punktu prawa oskarżonego do obrony można uznać wyrok SN z 12 maja 2011 r. (II KK 97/11, OSNKW 2011/7/63) przyjmujący, że przepis art. 443 k.p.k. pozwalający orzekać na niekorzyść oskarżonego przy ponownym rozpoznaniu sprawy na skutek uchylenia w wyniku środka zaskarżenia wniesionego na korzyść

$30 \quad$ Ibidem, s. 15

31 J. Grajewski, S. Steinborn, (w:) Kodeks postępowania karnego, op. cit., s. 67-69 oraz podana tam literatura. 
oskarżonego od wyroku skazującego wydanego w trybie art. 387 k.p.k., gdy środek ten kwestionował karę objętą uprzednim porozumieniem (art. 434 § 3 k.p.k.), nie dotyczy sytuacji, gdy kara ta została orzeczona niezgodnie z wymogami materialnego prawa karnego, a sąd, uwzględniając wniosek oskarżonego o skazanie go w określony sposób, nie wskazał mu na konieczność zmiany tego oświadczenia w danym zakresie, gdyż wówczas naruszenie prawa jest wynikiem wadliwego działania sądu, a oskarżony nie może ponosić negatywnych konsekwencji wydania przez sąd orzeczenia niezgodnego z prawem, zatem w pełni obowiązuje tu także w postępowaniu ponownym zakaz reformationis in peius.

Warto więc wskazać na uchwałę składu 7 sędziów SN z dnia 25 września 2013 r. (I KZP 5/2013, Biuletyn Sądu Najwyższego 2013/9) stwierdzającą, że: „Kontrolę instancyjną wyroku wydanego w trybie określonym w art. 343 k.p.k., poza modyfikacją wynikającą z art. 434 § 3 k.p.k., przeprowadza się na zasadach ogólnych.” Za istotne $\mathrm{z}$ punktu widzenia zagrożeń dla prawa oskarżonego do obrony (np. ze strony prokuratury), z którego w zasadzie zrezygnował zawierając porozumienie można uznać kilkakrotnie akcentowaną tezę z uzasadnienia uchwały, głoszącą, że w przypadku zaskarżenia wyroku zapadłego wskutek porozumienia procesowego (także przez prokuratora), traci ono swój byt, otwierając drogę do reformatoryjnego orzeczenia sądu odwoławczego.

W kontekście nowelizacji k.p.k. dokonanej ustawą z 27 września 2013 r. (Dz.U. z 25 października 2013 r., poz. 1247) to przewiduje ona wobec osób skazanych z zastosowaniem jednego z trybów konsensualnych (art. 343, art. 343a oraz art. 387 k.p.k.) zakaz powoływania jako podstawy apelacji zarzutu błędu w ustaleniach faktycznych i zarzutu rażącej niewspółmierności kary (art. 438 pkt. 3 i 4), które związane są z treścią zawartego przez tę stronę porozumienia (nowe brzmienie art. $447 \S 7$ k.p.k.). Apelacja oparta na takich podstawach zostanie uznana za niedopuszczalną ,jako kontestująca samą istotę porozumienia dobrowolnie zawartego przez stronę" . Jak wskazuje projektodawca, strona jednak będzie mogła wnieść apelację od wyroku wydanego z zastosowaniem jednego z tych trybów, jeśli ,podstawą środka odwoławczego uczyni jakikolwiek inny zarzut (t.j. naruszenie prawa materialnego, w tym nie tylko prowadzące do błędnej kwalifikacji prawnej czynu przypisanego, ale także polegające np. na wymierzeniu kary poza ustawowymi granicami sankcji, a także naruszenie prawa procesowego, mogące mieć wpływ na treść wydanego orzeczenia, w tym także związane z naruszeniem ustawowych warunków zakończenia sprawy w trybie konsensualnym) i wówczas jest, bez żadnych wyłączeń, chroniona zakazem reformationis in peius" ${ }^{32}$.

Szukając aksjologicznego bądź pragmatycznego uzasadnienia zróżnicowania negatywnych konsekwencji, jakie mogą spotkać w postępowaniu odwoławczym „wiarołomnych tzw. małych świadków koronnych” (ograniczenie zakazu reforma- 
tionis in peius $\mathrm{z}$ art. 434 § 4) oraz osób skazanych w trybach konsensualnych (zakaz $\mathrm{z}$ art. $447 \S 7$ k.p.k.) nie można ograniczyć się do stwierdzenia projektodawców, że takie rozwiązanie ,podjęte zostało przy zastosowaniu modelu całkowicie odmiennego od określonego w noweli styczniowej i uznanego przez Trybunał za sprzeczne, w pewnych warunkach, z wzorcami konstytucyjnymi" 33 . Przede wszystkim należy zauważyć, że o ile „wiarołomni mali świadkowie koronni” nie są wprawdzie chronieni dobrodziejstwami zakazu reformationis in peius, to jednak ustawodawca nie ogranicza ich w zakresie podstaw odwoławczych, jak to czyni w przypadku przy składaniu osób skazanych w trybach konsensualnych (art. 343, 343a i 387). Taka swoista dyskryminacja tej ostatniej grupy skazanych ma niewątpliwie uzasadnienie pragmatyczne wynikające $\mathrm{z}$ chęci przyspieszenia postępowania (expressis verbis powoływanego w uzasadnieniu projektu jako główny motyw zmian modelu postępowania odwoławczego), z drugiej zaś z zasady stabilności orzeczeń (tu opartej o zasadę pacta sunt serwanda). Warto w tym miejscu wskazać, że P. Kardas, posiłkując się poglądami doktryny poddającymi w wątpliwość zgodność trybów konsensualnych z zasadą prawdy materialnej, uznaje wzgląd na ochronę stabilności orzeczeń jako jeden $z$ wyjątków od tej zasady ${ }^{34}$. Poza tym analiza praktyki funkcjonowania tych porozumień (których zakres projekt jakościowo rozszerza) oraz analiza orzecznictwa SN wskazuje, że porozumienia takie zarówno w Polsce, jak i np. w systemie anglosaskim budzą wątpliwości w kontekście ich zgodności z gwarancjami rzetelnego procesu ${ }^{35}$.

Natomiast jeśli chodzi o zgodność ograniczenia z art. 447 § 7 k.p.k. ze wskazanym na wstępie standardem konwencyjnym i konstytucyjnym, to jak stwierdza się w literaturze przedmiotu, w świetle art. 176 Konstytucji oraz art. 2 Protokołu nr 7 EKPCz za niezgodne ze standardem prawa do odwołania określonym w tych regulacjach należałoby uznać ${ }^{36}$ :

a) ograniczenia kontroli odwoławczej wyłącznie do bezwzględnych przyczyn odwoławczych,

b) ograniczenie przyczyn odwoławczych wyłącznie do naruszeń prawa, a wyłączenie z zakresu kontroli ustaleń faktycznych,

c) wyłączenie rażącej niewspółmierności kary (art. 438 pkt 4 k.p.k.) z katalogu podstaw, czy ograniczenie kontroli w zakresie wymiaru kary do obrazy prawa materialnego,

d) wyłączenie możliwości zaskarżenia orzeczenia co do kary przez oskarżenie (niezgodne z art. 32 ust. 1 i art. $78 \mathrm{w}$ zW. $\mathrm{z}$ art. 176 ust. 1 Konstytucji), tak

Ibidem, s. 96.

P. Kardas, Zasada prawdy materialnej a kontradyktoryjność postępowania dowodowego, op. cit., s. 73.

Zob. np. monografię, C. Kulesza (red.), Criminal plea bargains in the English and the Polish Administration of justice systems in the context of the fair trial guarantees), Białystok 2011.

S. Steinborn, Ograniczenia zaskarżalności wyroku wydanego w I instancji jako środek uproszczenia procesu karnego w świetle prawa do dwuinstancyjnego postępowania, GSP 2005, t. 13, s. 382-386 oraz P. Wiliński, Proces..., op. cit., s. 158-159 i podane tam orzecznictwo TK. 
więc ewentualne ograniczenia mogą dotyczyć jedynie zarzutu obrazy przepisów prawa materialnego (art. 438 pkt. 1 k.p.k.) i obrazy przepisów postępowania, jeśli mogła mieć ona wpływ na treść orzeczenia (art. 438 pkt. 2 k.p.k.).

Należy dodać, że do środków odwoławczych wnoszonych przez skazanych w trybach konsensualnych (art. 343, 343a i 387) będą się odnosiły także ogólne ograniczenia z art. $427 \S 4$ i odnośnie apelacji - art. $447 \S 5$ k.p.k. Nowa treść art. $427 \S 4$ zakazuje podniesienia w środku odwoławczym zarzutu nieprzeprowadzenia przez sąd określonego dowodu, jeżeli strona nie składała w tym zakresie wniosku dowodowego, ani też zarzutu przeprowadzenia dowodu, pomimo braku wniosku strony w tym przedmiocie lub poza zakresem wniosku. Natomiast art. $447 \S 5$ zabrania w postępowaniu wszczętym $\mathrm{z}$ inicjatywy strony podnosić w apelacji zarzutu niedopuszczenia dowodu z urzędu lub niedostatecznej aktywności sądu w przeprowadzaniu dowodu ani też zarzutu przeprowadzenia dowodu pomimo braku wniosku strony w tym przedmiocie.

Tak więc wątpliwości może budzić zgodność wprowadzonych nowelizacją ograniczeń zaskarżalności wyroków zapadłych wskutek porozumień procesowych ze standardem konstytucyjnym, jako nawiązującymi do punktów b/ i c/ negatywnego katalogu opracowanego przez S. Steinborna. W tym kontekście istnieje niebezpieczeństwo funkcjonowania w obrocie prawnym prawomocnych orzeczeń, które nie będą oparte o prawdziwe ustalenia faktyczne (mimo utrzymania przez nowelizację formalnego wymogu stosowania trybów skróconych, że okoliczności popełnienia czynu nie budzą wątpliwości). Dostrzegając fikcyjność takiej przesłanki ograniczającej sami Twórcy reformy stwierdzają niekiedy wprost: „Wydaje się zatem, że uczciwiej byłoby powiedzieć wprost, że podstawą rozstrzygnięcia jest nie tylko konsensus co do rodzaju i wymiaru kary, ale także konsensus co do okoliczności popełnienia czynu"37.

Wskazane wyżej ograniczenia możliwości zaskarżania wyroków zapadłych wskutek porozumień procesowych uzasadniają obawy, że takie prawomocne wyroki mogą naruszać zasadę trafnej reakcji karnej (art. $2 \S 1$ pkt 1 k.p.k.) ${ }^{38}$ lub też zasadę prawdy materialnej (art. $2 \S 2$ k.p.k.) ${ }^{39}$. Orzeczenia takie mogą stwarzać wrażenie w społeczeństwie, że istnieje możliwość negocjowania, jaką poniesie się odpowiedzialność karną nawet w przypadku najpoważniejszych przestępstw. W kontekście

37 P. Hofmański, Zasada prawdy w postulowanym modelu procesu karnego, (w:) K. Kremens, J. Skorupka (red.), Pojęcie, miejsce i znaczenie prawdy w polskim procesie karnym Wrocław 2013, s. 46.

38 Zob. np. C. Kulesza, Sprawiedliwa kara a konsensualne formy zakończenia postępowania karnego (uwagi na tle orzecznictwa sądowego), (w:) W. Cieślak, S. Steinborn (red.), Profesor Marian Cieślak - osoba, dzieło, kontynuacje, Warszawa 2013, s. 923-941.

39 Zob. np. C. Kulesza, Legalizm i oportunizm ścigania a prawa pokrzywdzonego w świetle nowelizacji polskiego ustawodawstwa karnego z 2013 r., (w:) Księga Pamiątkowa Prof. Janusza Tylmana (w druku); R. Kmiecik, Legalizm i konsensualizm w działalności karnoprocesowej prokuratora - między teorią i praktyką, (w:) T. Grzegorczyk (red.), Funkcje procesu karnego Księga jubileuszowa Profesora Janusza Tylmana), Warszawa 2011, s. 25-35. 
równości obywateli wobec prawa obawy może budzić pogłębianie się faktycznej nierówności między oskarżonymi, gdyż osoby o wyższym statusie majątkowym będą mogły korzystać z usług dobrych i skutecznych obrońców z wyboru, którzy skutecznie przeprowadzą negocjacje z prokuratorem i sądem. Niebezpieczeństwo powyższych zagrożeń wzrośnie nie tylko wskutek rozszerzenia zakresów tych trybów, lecz wskutek zwiększenia kontradyktoryjności postępowania karnego. Jak wskazują bowiem chociażby doświadczenia amerykańskie, im większy ciężar gatunkowy spraw i potencjalnie wyższy stopień ich skomplikowania dowodowego, tym większe niebezpieczeństwo, że porozumienia procesowe staną się dla oskarżycieli publicznych sposobem uniknięcia ryzyka związanego z konieczności udowadniania winy oskarżonemu w trakcie kontradyktoryjnej rozprawy. Natomiast dla sędziów kwestia, czy zaakceptować propozycję konsensualnego zakończenia procesu może sprowadzać się do dylematu, czy szybko rozstrzygnąć sprawę czy też prowadzić długotrwałe postępowanie dowodowe, a następnie sporządzać obszerne uzasadnienie wyroku ${ }^{40}$.

Za pozytywne, w kontekście zmian w zakresie trybów konsensualnych należy jednak uznać, że nowelizacja z 27 września 2013 r. doprecyzowuje przepis art. 343 k.p.k., poprzez urealnienie gwarancji procesowych pokrzywdzonego, który będzie miał zagwarantowane prawo sprzeciwu wobec wydania wyroku bez przeprowadzenia rozprawy (nowy $\S 3 \mathrm{a}$ ), a także wyraźne zapisanie w $\S 3$ b, że sąd może uzależnić uwzględnienie wniosku od dokonania w nim wskazanej przez siebie zmiany, zaakceptowanej przez oskarżonego. Proponowana zmiana musi być także zaakceptowana przez oskarżyciela, albowiem w wypadku braku akceptacji z jego strony, wniosek o skazanie bez rozprawy może po prostu cofnąć, co spowoduje konieczność rozpoznania sprawy na zasadach ogólnych.

Można zasadnie stwierdzić, że zakaz z art. 447 § 7 k.p.k. stanowiący, że podstawą apelacji nie mogą być zarzuty określone w art. 438 pkt 3 i 4, związane z treścią zawartego porozumienia, o którym mowa w art. 343, art. 343a i art. 387 odnosi się (przynajmniej jak wynika z uzasadnienia projektu nowelizacji) jedynie do osób skazanych w tych trybach konsensualnych, a nie do pokrzywdzonego. Trudno bowiem uznać, że jeśli nie skorzysta on z prawa do sprzeciwu wobec porozumienia, automatycznie staje się jego stroną. W związku z powyższym należy uznać, że pokrzywdzony, który zapobiegliwie wykorzystał prawo do uznania go za oskarżyciela posiłkowego w sprawie, nie będzie związany ograniczeniami z art. 447 § 7 k.p.k. i będzie mógł wnieść apelację na podstawach określonych także w art. 438 § 3 i 4 (oczywiście zgodnie z wymogami instytucji gravamenu z art. 425 k.p.k. - na niekorzyść oskarżonego).

Konkludując powyższe rozważania można zasadnie wskazać, że w znowelizowanej od dnia 1 lipca 2015 r. procedurze karnej, gdzie zgodnie z art. 14 § k.p.k. 
prokurator będzie mógł do rozpoczęcia przewodu sądowego na I rozprawie w oparciu o nieokreślone kryteria skutecznie wycofać akt oskarżenia ${ }^{41}$ (sąd wówczas umorzy postępowanie, chyba że do sprawy wstąpi w trybie art. $54 \S 2$ pokrzywdzony jako oskarżyciel posiłkowy), zaś rozszerzenie zakresu trybów konsensualnych może wzmocnić oportunizm faktyczny prokuratury to właśnie pokrzywdzonemu przypadnie rola „Kassandry państwa prawa” ${ }^{42}$.

\footnotetext{
41 Po rozpoczęciu przewodu sądowego skuteczne wycofanie aktu oskarżenia będzie oczywiście wymagało zgody oskarżonego. I dopiero w trakcie postępowania dowodowego na rozprawie będzie aktualizowało się kryterium takiego wycofania skargi przewidziane przez zmieniony przez nowelizację z 27 września 2013 r. przepis art. 32 ust. 2 ustawy z dnia 20 czerwca 1985, a mianowicie, że prokurator cofa akt oskarżenia, jeżeli wyniki postępowania sądowego nie potwierdzają zarzutów oskarżenia. 


\section{CHALLENGING JUDGMENTS ISSUED IN CONSENSUAL MODES OF CRIMINAL PROCEEDINGS - EUROPEAN STANDARD AND POLISH LAW}

The author deals with the right to appeal against judgments issued in negotiated case-ending settlements in the light of Art. 2 of Protocol No. 7 to the Convention for the Protection of Human Rights and Fundamental Freedoms and the Polish Constitution. The analysis includes ECHR case law which indicates that the possibility of appeal against court decisions is one of the guarantees of the right to defense. It also highlights the judgments of the Constitutional Court and the Supreme Court concerning the principle of two-instance appeal proceedings, the right to trial and the reformationis in peius prohibition. From these considerations it is concluded that the Polish Code of Criminal Procedure of 1997 meets, but only in ordinary mode of proceedings, both standards: the standard adopted in Protocol No. 7 of the Convention and the constitutional standard.

Considerations also included changes in the consensual modes of criminal proceedings introduced by the reform of the Polish Code of Criminal Procedure of 27 September 2013, which points out, inter alia, that the primary limitation of the right to appeal against the judgments issued in these modes is amended Art. $447 \S 5$, in that it provides to persons convicted of using one of such modes of proceedings (Art. 343, Art. 343a and Art. 387 of the Code) non-appointment as grounds for appeal error of fact and flagrant disproportion of penalties and of penal measures (art.438 paragraph .3 and 4), which are related to the content of the agreement. Such limitations justify the fear that such final judgments may violate the principle of criminal accurate response (Article $2 \S 1$ point 1 of the Code), or the principle of material truth (Article $2 \S 2$ of the Code of Criminal Procedure).

Keywords: reform of criminal procedure, consensual modes of proceedings, limitation of the right to appeal, constitutional standard, principle of material truth, error of fact 